\title{
PENANAMAN NILAI-NILAI PENDIDIKAN ANTIKORUPSI MELALUI HABITUS KETELADANAN DI SMP MUHAMMADIYAH BOARDING SCHOOL YOGYAKARTA
}

\author{
Moh. Wahyu Kurniawan, Rini Setiyowati \\ Universitas Muhammadiyah Malang \\ Universitas Sriwijaya \\ mohwahyukurniawan@gmail.com \\ Rinisetiyowati494@gmail.com
}

\begin{abstract}
Abstrak
Penelitan ini bertujuan untuk memberikan gambaran tentang habituasi atau pembiasaan nilai-nilai pendidikan antikorupsi di sekolah dengan basic islamic boarding school. Metode penelitian menggunakan pendektaan kualitatif dengan metode fenomenologi. Penelitian ini dilakukan di SMP Muhammadiyah Boarding School Yogyakarta. Informan dalam penelitian ini yaitu kepala sekolah, guru, pembina ekstrakulikuler, pembina asrama serta siswa. Hasil penelitian ini menunjukkan bahwa penanaman nilai-nilai pendidikan antikorupsi melalui keteladan dapat dilakukan secara holistik baik melalui pembelajaran, ekstrakulikuler maupun pembiasaan di asrama. Pendidikan antikorupsi sebagai pendidian akan nilai kedepannya harus mendapatkan penangan yang serius untuk membangun generasi antikorupsi
\end{abstract}

Kata Kunci: Pendidikan antikorupsi, Boarding School.

\begin{abstract}
This research aims to provide an overview of the integration strategy of anticorruption education in schools on the basis of islamic boarding school. The research method uses kualtitatif approach with phenomenological method. This research was conducted in SMP Muhammadiyah Boarding School Yogyakarta. The informants ie principals, teachers, extracurricular builder, builder dormitories, and students. collecting data through interviews, observation and documentation. The results showed that the integration of anti-corruption education is done through habituation in a dormitory, habituation through extracurricular activities, as well as familiarity with the culture of the school. Anti-corruption education as the future value of education will have to get serious treatment in order to build the next generation of anti-corruption.
\end{abstract}

Keywords: Anti-corruption education, Boarding School

\section{PENDAHULUAN}

Perkembangan peradaban sebuah bangsa dimulai dari peradaban sistem pendidikannya. Pembangunan sistem pendidikan diharapkan dapat menjadi solusi untuk menyelesaikan permasalahan kontemporer bangsa. Salah satu masalah kontemporer yang dialami bangsa Indonesia adalah berkembangnya mental korupsi sebagai penyakit sosial yang kerap menjadi penyebab runtuhnya peradaban maju.

Upaya pemberantasan korupsi melalui KPK yang dilakukan sejak berdirinya KPK pada tahun 2002 sudah menunjukkan hasil kinerja yang baik. Hal ini terbukti dengan rilis dari Transparency Internasional tahun 2015, menempatkan Indonesia pada posisi ke-88 dengan Indeks Persepsi Korupsi (IPK) 36, mengalami peningkatan dari tahun 2014 dengan IPK 34 serta IPK 32 
pada tahun 2012 dan 2013. Kendati skor IPK Indonesia mengalami peningkatan, Indonesia masih dalam taraf negara dengan indeks korupsi terbesar di dunia.

Berdasarkan hasil rilis Transparency International 2015, rata-rata skor IPK secara global berada pada angka 43. IPK Indonesia pada angka 36 belum mampu mencapai IPK rata-rata global serta regional negara ASEAN Indonesia belum bisa menandingi IPK Malaysia 50, Singapura 85, serta Thailand 38. Indonesia memiliki IPK lebih baik dibandingkan dengan Filiphina 35, Vietnam 31, dan jauh di atas Myanmar 22. Melihat pada nilai IPK Indonesia dapat disimpulkan bahwa kinerja KPK juga harus dibantu oleh masyarakat dalam upaya mencegah dan memberantas segala bentuk korupsi di semua bidang kehidupan bangsa.

Upaya pemberantasan korupsi di Indonesia haruslah terprogam, holistik dan memiliki tolak ukur yang jelas dalam pelaksanaanya. Kejelasan tolak ukur upaya pemberantasan korupsi akan membuat progam tersebut dapat diteruskan pada generasi selanjutnya, karena nilainya tetap. Salah satu cara memberantas korupsi hingga akarnya ialah melalui jalur pendidikan. Keterlibatan pendidikan formal dalam upaya pencegahan korupsi memiliki kedudukan strategis dan antisipatif, upaya pencegahan korupsi di masyarakat terlebih dahulu dapat dilakukan dengan mencegah berkembangnya mental korupsi pada anak bangsa melalui pendidikan (Nuriani Laura, dkk. 2014: 94). Urgensi pengintegrasian pendidikan antikorupsi dalam sistem pendidikan nasional memang harus ditindak lanjuti dengan serius, hal ini guna sedini mungkin melakukan upaya pencegahan berkembangnya korupsi.

Pendidikan antikorupsi secara umum menurut Dharma Kesuma, dkk. (2009:
59) memiliki tujuan sebagai berikut: (1) pembenahan informasi untuk pembentukan pengetahuan dan pemahaman mengenai berbagai bentuk korupsi dan aspek-aseknya, (2) pengubahan persepsi dan sikap terhadap korupsi, (3) pembentukan keterampilan dan kecakapan baru yang dibutuhkan untuk melawan korupsi. Tiga tujuan pendidikan antikorupsi menurut Dharma Kesuma, dkk. (2009), sinergi dengan rumusan nilai-nilai pendidikan antikorupsi yang dikemukan oleh Agus Wibowo (2013: 45) meliputi kejujuran, kepedulian, kemandirian, kedisiplinan, tanggung jawab, kerja keras, kesederhanaan, keberanian, serta keadilan.

Di sisi lain Agus Wibowo (2013: 38) memberikan pendapat bahwa pendidikan antikorupsi merupakan usaha sadar dan terencana untuk mewujudkan proses belajar yang kritis terhadap nilai-nilai anti korupsi. Pendidikan antikorupsi dapat diartikan sebagai usaha sadar untuk merubah mental korupsi menjadi mental antikorupsi tidak hanya melalui transfer pengetahuan (kognitif). Namun juga menekankan pada upaya pembentukan karakter (afektif), dan kesadaran moral (psikomotor) dalam melakukan perlawanan terhadap penyimpangan perilaku korupsi. Diperkuat dengan pendapat Rosida Tiurna (2012: 237) bahwa pendidikan antikorupsi merupakan pendidikan yang ditinjau dari sudut pandang nilai-nilai moral dengan pembelajaran yang khas bercirikan pembentukan karakter.

Pendidikan antikorupsi sebagai wadah untuk membentuk mental atau karakter antikorupsi, sejalan dengan tujuan pendidikan karakter yaitu membentuk warga negara yang berkarakter antikorupsi. Kesinambungan tujuan ini dapat dipadukan menjadi satu kesatuan dalam proses pembelajaran untuk

Moh. Wahyu K, Rini S. Penanaman Nilai-Nilai Pendidikan Antikorupsi Melalui Habitus Keteladanan di SMP Muhammadiyah Boarding School Yogyakarta 
mengatasi permasalahan korupsi. Pengembangan serta pengintegrasian pendidikan antikorupsi di sekolah bukan berarti tidak menimbulkan permasalahan baru. Permasalahan yang muncul dalam mewujudkan pendidikan antikorupsi di sekolah adalah cara yang digunakan untuk mewujudkannya.

Sejalan dengan strategi pengembangan pendidikan karakter, pendidikan antikorupsi disisipkan dan diintegrasikan pada mata pelajaran. Pendidikan antikorupsi dimasukkan dalam kurikulum sekolah namun tidak dalam satu mata pelajaran, pendidikan antikorupsi diinterasikan dalam mata pelajaran yang ada (Harmanto, 2008). Diperkuat oleh Lukman Hakim (2012: 144) bahwa secara sederhana, pendidikan antikorupsi diintegrasikan pada mata pelajaran Pendidikan Agama Islam dan Pendidikan Kewarganegaraan, hal ini dikarenakan pendidikan untuk mengurangi korupsi merupakan pendidikan nilai, mendorong setiap generasi menyusun kembali sistem nilai yang diwarisi dari kebudayaan yang baik.

Pendidikan antikorupsi sebagai pendidikan akan nilai antikorupsi, belum cukup jika hanya melalui pembelajaran saja, akan tetapi juga harus dibantu melalui budaya sekolah, terutama dalam konteks penanaman nilai dan pembentukan karakter antikorupsi peserta didik agar memiliki sikap dan perilaku antikorupsi, budaya sekolah disebut juga dengan civic culture. Budaya sekolah dapat dikembangkan melalui kegiatan intrakulikuler dan ekstrakulikuler dengan melibatkan semua warga sekolah.

Pengembangan budaya sekolah serta pembentukan karakter peserta didik akan lebih mudah dilakukan jika sekolah dapat melakukan pengawasan selama 24 jam kegiatannya. Pengawasan dilakukan untuk dapat mengkontrol progam yang dijalankan, hal ini dapat dilakukan melalui sistem boarding school. Boarding school merupakan sistem pendidikan yang memadukan sistem asrama dengan sistem pendidikan nasional pada umumnya, dalam perpaduan dua sistem ini pengembangan yang diberikan adalah pendidikan sarat dengan nilai, baik nilai agama maupun nilai luhur bangsa. Salah satu sekolah di Kabupaten Sleman yang telah menerapkan sistem boarding school adalah Muhammadiyah Boarding School (MBS) Yogyakarta. MBS merupakan lembaga pendidikan dengan komitmen kuat untuk mengembangkan karakter peserta didik secara holistik dalam setiap sistem pendidikannya, baik melalui pembelajaran maupun pembiasaan. Berangkat dari degradasi moral yang terus menggerus karakter anak bangsa, MBS menginternalisasikan pendidikan karakter dalam sistem boarding school.

Kesinambungan pendidikan antikorupsi dengan pendidikan karakter di SMP Muhammadiyah Boarding School Yogyakarta, menjadikan penting untuk diteliti bagaimana proses pengintegrasian pendidikan antikorupsi di SMP Muhammadiyah Boarding School, hal ini juga dikarenakan secara kurikulum KTSP materi antikorupsi ada di kelas VIII yang menunjukkan bahwa siswa SMP sudah bisa menerima materi tentang korupsi. Penelitian ini bertujuan menganaslisis strategi pengintegrasian pendidikan antikorupsi di SMP Muhammadiyah Boarding School Yogyakarta melalui pembiasaan .

\section{METODE PENELITIAN}

Penelitian ini menggunakan pendekatan kualitatif dengan metode fenomenologi untuk mencari menggali informasi terkait dengan pembiasaan pendidikan antikorupsi 
di SMP Muhammadiyah Boarding School Yogyakarta. Informan dalam penelitian ini adalah kepala sekolah, guru, pembina asrama, pembina ekstrakulikuler, serta siswa. Data hasil wawancara, observasi, dan dokumentasi yang telah terkumpul akan dilakukan reduksi data menjadi data sederhana. Data dikelompokkan berdasarkan kerangka kerja konseptual, pertanyaan penelitian, dan instrument penelitian yang digunakan. Kemudian melakukan perangkuman data, pengkodean, pengelompokkan, dan penyajian data secara tertulis. Kemudian dilakukan penyajian data sebagai informan terstruktur yang memungkinkan untuk diintepretasikan dan disimpulkan.

\section{HASIL DAN PEMBAHASAN}

Proses pengintegrasian pendidikan antikorupsi melalui pembiasaan atau penanaman nilai-nilai antikorupsi di SMP Muhammadiyah Boarding School merupakan cara pihak sekolah, asrama, serta para pengasuh untuk menanamkan pembiasaan nilai-nilai antikorupsi sebagai wujud pendidikan antikorupsi. Pembiasaan yang dilakukan oleh SMP Muhammadiyah Boarding School ini berangkat dari korupsi yang terjadi di semua elemen masyarakat. Usaha membentuk mental antikorupsi di SMP Muhammadiyah Boarding School dilakukan secara holistik baik melalui pembelajaran maupun kegiatan keseharian. Hal ini disampaikan oleh Bapak Agus Yulianto selaku kepala sekolah bahwa penanaman pendidikan antikorupsi di sekolah terutama di SMP Muhammadiyah Boarding School Yogyakarta, selain melalui pengintegrasian pada mata pelajaran juga melalui pembiasaan. Pembiasaan menjadi sistem kemudian sistem menjadi budaya sehingga budaya akan membentuk karakter. Apalagi masyarakat kita memiliki kebiasaan membenarkan budaya, padahal seharusnya membudayakan yang benar.

Pembiasaan nilai-nilai antikorupsi di SMP Muhammadiyah Boarding School berusaha dilakukan secara menyeluruh. Hal ini untuk dapat membentuk budaya serta karakter antikorupsi. Merubah dari membiasakan serta membenarkan budaya menjadi membudayakan dan membiasakan yang benar di SMP Muhammadiyah Boarding School memerlukan proses yang tidak sebentar. Bapak Fahrizal selaku guru PKn juga memberikan pandangan untuk mengintegrasikan pendidikan antikorupsi selain melalui mata pelajaran kembali lagi melalui ketaladanan. Misalnya jika membicarakan terkait dengan korupsi waktu, ketidakjujuran, dan ketidakdisiplinan bisa diberikan contoh melalui keteladanan, guru menyuruh anak untuk tidak telat sebisa mungkin guru diusahakan untuk tidak telat.

Bapak Odjie Samroji selaku pembina asrama memberikan pernyataan bahwa pendidikan antikorupsi hampir sama dengan pendidikan karakter sehingga cara yang efektif untuk menanamkan nilai-nilai antikorupsi melalui pembiasaan serta keteladanan baik di sekolah maupun asrama. Dipertegas dengan pernyataan Bapak M. Fauzan Yaksya selaku pembina ekstrakulikuler bahwa pendidikan antikorupsi pada dasarnya masih sangat abstrak, akan tetapi nilai-nilai antikorupsi dekat dengan nilai-nilai karakter. Sedangkan karakter adalah sesuatu yang dikembangkan di MBS. Berangkat dari hal ini untuk dapat membiasakan atau membentuk sikap antikorupsi bisa melalui pembiasaan serta pemberian contoh dari guru serta seluruh elemen sekolah, dengan begitu anak paham akan hal-hal kecil dan sederhana yang termasuk nilai-nilai antikorupsi, karena korupsi dalam diri

Moh. Wahyu K, Rini S. Penanaman Nilai-Nilai Pendidikan Antikorupsi Melalui Habitus Keteladanan di SMP Muhammadiyah Boarding School Yogyakarta 
anak-anak tidak hanya dengan mengambil uang tapi juga waktu dll.

Pendidikan antikorupsi di SMP Muhammadiyah Boarding School dimaknai sebagai bagian dari pendidikan karakter yang memang dikembangkan secara menyeluruh di Muhammadiyah Boarding School. Dari berbagai pernyataan yang disampaikan oleh narasumber dapat dikatakan pendidikan antikorupsi lebih pada pendidikan akan nilai-nilai moral dan karakter sehingga dalam pengembangannya SMP Muhammadiyah Boarding School lebih pada memberikan pembiasaan serta dengan keteladanan yang diberikan oleh seluruh elemen sekolah. Keteladanan dan pembiasaan ini diharapkan akan menjadi budaya baru, budaya antikorupsi pada siswa Muhammadiyah Boarding School. Bapak Agus Yulianto selaku kepala sekolah juga memberikan pernyataan bahwa cara untuk merubah budaya korupsi dengan pembudayaan. Pembudayaan untuk mencegah berkembangnya mental korupsi sederhanannya dengan cara memberikan sanksi ketika guru maupun siswa telat.

Penanaman akan nilai-nilai karakter yang baik menjadi sangat penting untuk dapat membangun atau membentuk karakter siswa. Nilai karakter ini juga lah yang dibangun oleh SMP Muhammadiyah Boarding School, dari hasil observasi didapatkan nilai-nilai yang dibangun oleh Muhammadiyah Boarding School adalah kekeluargaan, keikhlasan, kejujuran, kebersamaa, kemandirian diaplikasikan dalam setiap kegiatan.

Penanaman nilai-nilai pendidikan antikorupsi dapat ditanamkan melalui pembiasaan yang menjadi budaya pada seluruh aktivitas siswa di sekolah. Kaitannya dengan pembiasaan pendidikan antikorupsi di SMP Muhammadiyah Boarding School merupakan cara yang dilakukan sekolah untuk menanamkan nilai-nilai antikorupsi sebagai wujud pendidikan antikorupsi. Pembiasaan nilainilai pendidikan antikorupsi di SMP Muhamamdiyah Boarding School dilakukan secara holistik baik dalam pembelajaran, ekstrakulikuler, serta pembiasaan di asrama. Pembiasaan secara holistik yang dilakukan ini bertujuan untuk membentuk mental antikorupsi yang kuat dalam diri siswa. Sehingga pembiasaan pendidikan antikorupsi di SMP Muhammadiyah Boarding School merupakan praktek mengenai cara individu untuk mengembangkan kebaikan agar memperoleh pengalaman atas perbuatanperbuatan yang dilakukan sehingga timbul kebermanfaatan pada diri siswa yaitu mental atau karakter antikorupsi.

Pembiasaan pendidikan antikorupsi disadari oleh pihak sekolah SMP Muhammadiyah Boarding School memang bukan sesuatu yang mudah sehingga memerlukan kerjasama antar semua pihak dengan sedikit pemaksaan. Hal ini sesuai dengan pendapat dari Edi Sudrajat (2011: 159-160) mengemukakan bahwa hakekat pembiasaan merupakan proses pembudayaan, pada awalnya terdapat sedikit pemaksaan pada akhirnya menetap dan bersifat otomatis melalui proses yang berulang-ulang. Dengan demikian, proses pembiasaan pendidikan antikorupsi di SMP Muhammadiyah Boarding School Yogyakarta merupakan proses pembelajaran yang membiasakan siswa untuk melakukan suatu hal secara berulangulang dan berkesinambungan agar tercipta karakter antikorupsi yang relatif menetap.

\section{Proses pembiasaan pendidikan antikorupsi melalui budaya sekolah}

Pembiasaan penanaman nilai-nilai antikorupsi di SMP Muhammadiyah Boarding School Yogyakarta, merupakan 
upaya untuk mengenalkan siswa mulai dari hal-hal yang sederhana tentang korupsi dan antikorupsi. Hal ini sesuai dengan pemaparan yang diberikan oleh Bapak Fahrizal cara untuk menangggulangi pemakluman, pembiasaan dan pembudayaan korupsi dicegah dengan upaya pembiasaan antikorupsi, sebagai guru bisa menggunakan kontrak belajar pada siswa kontrak belajar ini seperti keterlambatan 15 menit siswa tidak boleh masuk kelas, ataupun masuk kelas tidak diabsen.

Melalui kegiatan observasi yang dilakukan pada proses belajar mengajar di SMP Muhammadiyah Boarding School Yogyakarta, didapatkan hasil bahwa kegiatan belajar di sekolah dimulai pada pukul 07.00 sampai 15.00 terdiri dari mata pelajaran umum serta mata pelajaran pesantren. Kaitannya dengan proses pembiasaan penanaman nilai-nilai antikorupsi yang dilakukan apabila siswa terlambat masuk kelas akan mendapatkan hukuman dari guru. Hukuman untuk siswa yang terlambat masuk kelas hingga pukul 07.20 dapat berupa tidak boleh masuk kelas, serta bisa saja mendapat hukuman tambahan seperti membaca Al-Quran. Pembiasaan ini untuk menanamkan nilai kedisiplinan serta tanggung jawab pada diri siswa, masalah waktu di SMP Muhammadiyah Boarding School Yogyakarta mendapat perhatian serius.

Kedisiplinan dalam hal waktu, dari pandangan guru PKn serta kepala sekolah SMP Muhammadiyah Boarding School Yogyakarta merupakan aspek penting untuk dibiasakan pada siswa. Menggunakan waktu sesuai dengan jadwal merupakan awal dari kedisiplinan serta memupuk sikap antikorupsi, hal ini dikarenakan tidak menghargai waktu atau terlambat merupakan pembiasaan awal dari pembiaran serta benih korupsi. Lebih lanjut Bapak Agus Yulianto memberikan contoh pembiasaan yang dibiarkan kemudian menjadi kasus menteri " $A$ " membiarkan Sekjennya korupsi maka menteri " $A$ ” yang terkena kasus korupsi, hal ini merupakan contoh pembiaran kecil namun dapat menjadi masalah.

Pembiasaan pendidikan antikorupsi melalui budaya sekolah dilaksanakan pada seluruh kegiatan di sekolah. Adapun proses pembiasaan yang dilakukan di SMP Muhammadiyah Boarding School Yogyakarta diantaranya dengan melakukan kontrak belajar, dimana siswa yang telah 15 menit tidak diizinkan untuk mengikuti pelajaran, disamping itu tidak hanya siswa yang terlambat saja akan tetapi siswa yang tidak serius atau mengantuk saat mengikuti pelajaran dalam kelas juga dipersilahkan untuk tidak mengikuti pelajaran. Hal ini untuk membiasakan kedisiplinan serta tanggung jawab siswa yang dimulai dari hal-hal sederhana pada pembelajaran di SMP Muhammadiyah Boarding School Yogyakarta. Sesuai dengan pendapat Agus Wibowo (2013: 45) bahwa kedisiplinan merupakan tindakan yang menunjukkan perilaku tertib dan patuh pada berbagai ketentuan dan peraturan.

Selanjutnya untuk membiasakan nilainilai kejujuran melalui budaya sekolah dengan membiasakan larangan serta hukuman yang tegas terkait mencontek. Mencontek atau plagiasi dalam terminologi Bast \& Linda (2008: 781) merupakan kegiatan membohongi diri sendiri karena menjadikan dirinya sebagai pemilik sebuah karya. Berangkat dari terminologi tersebut siswa SMP Muhammadiyah Boarding School yang ketahuan mencontek akan mendapatkan hukuman tegas, hukuman ini dapat berupa pengurangan nilai, nilai menjadi nol, ujian ulang sampai pada

Moh. Wahyu K, Rini S. Penanaman Nilai-Nilai Pendidikan Antikorupsi Melalui Habitus Keteladanan di SMP Muhammadiyah Boarding School Yogyakarta 
hukuman tidak dinaikkan kelas. Nilai kejujuran melalui larangan mencontek menurut beberapa sumber di SMP Muhammadiyah Boarding School merupakan nilai penting yang harus dikembangkan secara serius, hal ini dikarenakan kejujuran merupakan pondasi penting dalam pembentukan mental antikorupsi serta menumbuhkan kepercayaan pada diri seseorang. Hal ini sesuai dengan pendapat dari Agus Wibowo (2013: 45) kejujuran merupakan perilaku yang didasarkan pada upaya menjadikan dirinya sebagai orang yang selalu dapat dipercaya dalam perkataan, tindakan, dan pekerjaan.

Kemudian, proses pembiasaan nilainilai pendidikan antikorupsi pada budaya sekolah diluar dari pembelajaran dapat berupa pembiasaan untuk shalat dhuha. Siswa di SMP Muhammadiyah Boarding School Yogyakarta memiliki jadwal setiap hari pukul 09.40-10.00 untuk melakukan shalat dhuha bersama. Pengembangan kegiatan ini akan semakin mendukung penanaman karakter kejujuran, tanggung jawab serta kedisiplinan siswa, hal ini dikarenakan untuk dapat membiasakan diri melakukan shalat dhuha setiap hari memerlukan karakter yang sudah tertata relatif baik. Sehingga, budaya sekolah yang dikembangkan oleh SMP Muhammadiyah Boarding School Yogyakarta telah memberikan pendidikan kognitif tingkat tinggi yaitu pada tahap moral action, atau pembentukan kebiasaan positif yang mampu membentuk budaya baru pembangun perubahan.

\section{Pembiasaan Pendidikan Antikorupsi di Asrama}

Pembiasaan nilai-nilai pendidikan antikorupsi di SMP Muhammadiyah Boarding School yang selanjutnya adalah melalui pembiasaan di asrama. Pembiasaan dilakukan melalui berbagai kegiatan di asrama, namun belum ada kegiatan khusus dengan lebel pendidikan antikorupsi, pembiasaan dikembangkan dan dimasukkan dalam nilai-nilai pendidikan karakter di MBS, hal ini disampaikan oleh Bapak Odjie Samroji selaku pembina asrama Muhammadiyah Boarding School.

Secara lebih lanjut Bapak Odjie Samroji memberikan penjabaran terkait dengan pembiasaan yang dikembangkan di asrama Muhammadiyah Boarding School, dalam proses pembiasaan nilai kedisiplinan kejujuran, tanggung jawab secara singkat dapat dilakukan dengan jadwal kegiatan rutin siswa. Berbicara tentang keadilan misalnya membagi jatah makanan yang sama tanpa adanya pilih kasih. Selanjutnya kesederhanaan dengan keterbatasan fasilitas di asrama membuat karakter kesederhanaan dengan lebih mudah terbentuk, kepedulian dengan berbagi pada teman satu kamar jika ada yang sakit atau memerlukan bantuan saling membantu.

Lebih lanjut tentang kedisiplinan sebagai wujud dari nilai karakter serta wujud dari salah satu nilai pendidikan antikorupsi sangat terlihat dari bagaimana santri tertib mengikuti kegiatan di asrama, ketertiban ini merupakan pembiasaan dari nilai-nilai kedisiplinan yang sangat terlihat jelas. Dipertegas dengan pernyataan Aula bahwa kedisiplinan di asrama sudah dibiasakan dari mulai bangun tidur untuk shalat Tahajjud hingga kegiatan menjelang tidur yang sudah tertata dengan rapi.

Kegiatan di asrama Muhammadiyah Boarding School dimulai pada pukul 03.30-04.00 untuk shalat tahajjud serta sahur jika berpuasa. Program unggulan harian dalam hal ibadah antara lain, puasa senin dan kamis, tahajjud dan dhuha pukul 09.40-10.00. Ini dimaksudkan 
sebagai upaya pembiasaan para siswa untuk gemar melakukan ibadah sunnah dan sekaligus sebagai pembentukan karekter siswa dalam hal peribadatan. Tertanamnya karakter dari pembiasaan ini bisa terlihat dari kesiapan sebagian siswa untuk melakukan ibadah lebih dari yang diprogramkan MBS. Sebagai contoh, puasa yang diprogramkan MBS, sementara ini, hanya puasa Senin dan kamis. Namun dalam praktiknya, banyak siswa yang justru melakukan puasa Daud (sehari puasa dan sehari berbuka) yang lebih berat dari puasa Senin dan kamis. Hal ini mengindikasikan bahwa para siswa sangat memahami arti sebuah ibadah.

Kegiatan laninnya adalah pukul 04.0004.30 shalat subuh berjamaah dilanjutkan dengan tahfidz, tahsin, MCK, serta makan pagi hingga pukul 06.40. Pukul 06.4007.00 kegiatan dilanjutkan dengan penyampaian mufrodat dan vocab. Pengayaan mufrodat merupakan suatu program yang bernaung di bawah bagian bahasa di organisasi kesiswaan IPM. Pengurus IPM bagian bahasa bertanggung jawab menyiapkan materi dan menyampaikannya kepada seuruh siswa setiap pagi 30 menit menjelang bel masuk KBM berbunyi, mufrodat yang disampaikan 2 bahasa sekaligus, Arab dan Inggris.

Siswa akan belajar di sekolah dari pukul 07.00-15.00, kemudian pukul 15.00 siswa akan melakukan kegiatan ektrakulikuler, dilanjutkan dengan kegiatan di asrama seperti tadarus, kajian kitab, shalat berjamaah, bimbingan belajar hingga persiapan untuk tidur pukul 22.00. Serangkaian kegiatan harian siswa ini memupuk rasa kejujuran dalam arti jujur mengikuti setiap kegiatan dengan mengisi daftar catatan sudah melakukan kegiatan sesuai jadwal atau belum, disiplin waktu, serta bertanggung jawab atas kegiatan yang dilakukan. Kaitannya dengan nilai-nilai pendidikan antikorupsi kegiatan ini merupakan proses pembentukan karakter yang dapat membentuk jiwa antikorupsi pada diri siswa.

Pembiasaan nilai-nilai pendidikan antikorupsi yang selanjutnya di SMP Muhammadiyah Boarding School Yogyakarta dilakukan melalui pembiasaan di asrama (Boarding School). Hampir sama dengan pembiasaan yang dilakukan melalui budaya sekolah, dalam pembiasaan melalui asrama juga dilaksanakan secara holistik atau menyeluruh. Sekolah dengan sistem Boarding School memiliki keunggulan yaitu sistem pembelajaran yang kontiniu secara 24 jam sehingga pembiasaan yang telah dilakukan di sekolah dapat diteruskan serta dikembangkan di asrama.

Proses pembiasaan nilai-nilai kejujuran, kedisiplinan, tanggung jawab, kemandirian, kerja keras diaplikasikan melalui ketaatan dalam mengikuti jadwal kegiatan sekolah dan asrama. Menjalankan kegiatan sesuai dengan aturan yang telah ditetapkan oleh pihak asrama maka dalam diri siswa secara tidak langsung telah berproses untuk memiliki karakter jujur, disiplin, mandiri, tanggung jawab serta kerja keras. Nilai-nilai ini dikembangkan oleh pihak asrama Muhammadiyah Boarding School dengan cara-cara yang sederhana namun dekat dengan keseharian siswa.

Lebih lanjut kaitannya dengan pembiasaan nilai-nilai keadilan juga dibiasakan oleh pihak asrama dengan secara sederhana seperti pemberian jatah makan yang sama, pemberian reward serta sanksi yang adil juga untuk para siswa yang melanggar peraturan, dengan demikian siswa di asrama Muhammadiyah Boading School tidak merasa ada

Moh. Wahyu K, Rini S. Penanaman Nilai-Nilai Pendidikan Antikorupsi Melalui Habitus Keteladanan di SMP Muhammadiyah Boarding School Yogyakarta 
diskriminasi, sehingga hal ini dapat membentuk mental antikorupsi dengan nilai keadilan di dalamnya. Keterbatasan fasilitas serta ruang gerak yang ada diasrama Muhammadiyah Boarding School juga mengajarkan pada siswa untuk memiliki sikap sederhana serta saling peduli dengan sesama.

Kemudian pembiasaan nilai-nilai pendidikan antikorupsi lainnya seperti kerja keras diwujudkan dengan memenuhi kebutuhannya sendiri selain melatih kemadirian juga melatih jiwa kerja keras dalam diri siswa di Muhammadiyah Boarding School. Siswa juga dipupuk untuk memiliki rasa keberanian dengan mengikuti organisasi kesiswaan seperti IPM, WH dan ekstrakulikuler lainnya. Peneliti melihat sistem asrama di Muhammadiyah Boarding School, memberikan pengalaman hidup secara langsung dalam mengimplmentasikan nilai-nilai pendidikan antikorupsi secara implisit dengan cara-cara yang sederhana sehingga mudah untuk diterima oleh siswa. Pengalaman hidup inilah yang menjadi titik awal pendidikan antikorupsi melalui pembiasaan dalam kehidupan sehari-hari.

Di samping itu untuk membiasakan nilai-nilai kesederhanaan terlihat dari keterbatasan yang ada di asrama. Aula juga memberikan pernyataan bahwa kesederhanaan merupakan pembiasaan yang sangat terasa ketika hidup di asrama, tidak boleh membawa HP, MP3, MP4, Laptop, TV juga tidak ada. Aturan yang ketat di asrama membuat santri membiasakan hidup sederhana, dari segi makanan juga dibiasakan untuk tidak pilihpilih makanan, menerima yang telah disediakan oleh pengasuh.

Pembiasaan kesederhanaan yang diaplikasikan di asrama terlihat juga dari hasil observasi yang dilakukan oleh peneliti ketika melihat para siswa sedang makan siang dengan berbagi bersama 2-3 teman dalam satu wadah yang sama. Sebagai wujud nilai-nilai pendidikan antikorupsi kesederhanaan yang dibiasakan pada siswa akan membentuk mental dan rasa bersyukur atas apa yang telah dimiliki sehingga dan menekan keinginan untuk mengambil yang bukan menjadi milikinya atau korupsi. Kesederhanaan melalui porsi makan juga melatih keadilan siswa dengan mengambil makanan sesuai dengan porsinya, walaupun dalam satu wadah disediakan untuk beberapa orang, hal ini dibuktikan dengan hasil observasi yang dilakukan oleh peneliti. Sistem pendidikan boarding school yang diterapkan di MBS, memberikan kesempatan dan peluang besar bagi pihak sekolah dan asrama untuk membiasakan karakter baik pada diri siswa.

Nilai pendidikan antikorupsi lainnya yang dapat dilihat di asrama adalah kerja keras dan keberanian. Kerja keras diwujudkan dengan siswa berusaha untuk memenuhi kebutuhannya sendiri dan kerja bakti, untuk keberanian dilatih dengan mengikuti organisasi IPM sebagai wadah untuk siswa bersosialisasi hal ini disampaikan oleh Bapak Odjie Sarmoji.

Pembiasaan nilai-nilai pendidikan antikorupsi seperti kerja keras diwujudkan dengan memenuhi kebutuhannya sendiri selain melatih kemadirian juga melatih jiwa kerja keras dalam diri siswa di Muhammadiyah Boarding School. Siswa juga dilatih untuk memiliki rasa keberanian dengan mengikuti organisasi kesiswaan seperti IPM.

Sementara itu Aula memberikan pernyataan bahwa, nilai tanggung jawab dilatih dengan pengelolaan uang saku, di asrama santri diberikan kebebasan untuk mengelola kelebihan uang saku masing- 
masing. Dengan demikian pembiasaan nilainilai pendidikan antikorupsi bisa disinergikan melalui pembiasaan karakter yang dikembangkan oleh Muhammadiyah Boarding School. Akan tetapi khusus untuk pendidikan antikorupsi itu sendiri harus didukung dengan proses penanaman pengetahuan melalui pembelajaran. Secara lebih lanjut dikemukakan oleh Bapak Odjie Darmoji selaku pembina asrama pendidikan antikorupsi masih abstrak, maka untuk membiasakannya melalui nilainilai karakter yang dikembangkan di MBS, pada dasarnya juga sama nilai-nilai antikorupsi merupakan bagian dari nilainilai karakter, sehingga harus diperkuat melalui aspek lain yaitu pembelajaran.

Sekolah dengan sistem asrama dapat menjadi sarana secara nyata dan langsung dalam memupuk karakter siswa, serta membentuk generasi antikorupsi. Pembentukan generasi antikorupsi diawali dengan pemupukan karakter yang kuat dalam diri siswa. Selanjutnya nilai antikorupsi yang dapat terlihat di asrama adalah kepedulian. Aula sebagai siswa SMP Muhammadiyah Boarding School Yogyakarta memberikan pernyataan sebagai ujud kepedulian terhadap sesama jika dari progam sekolah ada ABAS (Amal Bakti Santri).

Dipertegas oleh pendapat dari bapak Odjie Samroji sebagai wujud kepedulian terlihat ketika ada sesama teman yang sakit saling merawat, serta jika ada yang mengalami kesulitan saling membantu. Kehidupan di asrama dimana 24 jam santri bersama dengan karakter yang berbedabeda akan memupuk rasa kepedulian satu sama lain walaupun ini memerlukan waktu untuk menumbuhkan rasa peduli.

Sembilan nilai pendidikan antikorupsi mulai dari kejujuran, kedisiplinan, kemandirian, tanggung jawab, kerja keras, kepedulian, keberanian, kesederhanaan dan keadilan dalam pengintegrasiannya tidak bisa dipisahkan satu per satu, karena akan selalu berhubungan. Kelebihan pengintegrasian dalam sekolah sistem asrama adalah pendidikan 24 jam dan terus menerus akan membuat nilai yang diajarkan lebih mudah untuk ditanamkan pada siswa.

Secara khusus hambatan pembiasaan nilai-nilai pendidikan antikorupsi di asrama SMP Muhammadiyah Boarding School relatif sangat kecil jika dalam pembiasaan itu memang sinergi dengan pendidikan karakter, mungkin yang menjadi hambatan adalah ketika harus memberikan label bahwa yang dilakukan merupakan proses pembiasaan dari pendidikan antikorupsi karena selama ini masih merupakan bagian dari pendidikan karakter. Selanjutnya, hambatan dapat dari pengasuh yang tidak semua tinggal di asrama, sehingga memiliki kultur atau budaya yang berbeda. Akan tetapi tetap diharapkan kedepannya dari berbagai model pendidikan akan tercipta generasi penerus yang antikorupsi.

Ditinjau dari teori habitus Bourdie bahwa habit merupakan struktur mental atau kognitif yang berhubungan dengan dunia sosial seseorang dalam ranah kapital tertentu, kehidupan sosial tidak dapat dipahami semata-mata sebagai agregat perilaku individu (Jenkins, 2010: 106). Perilaku siswa SMP Muhammadiyah Boarding School Yogyakarta, terbentuk dengan adanya dorongan kehidupan sosial yang mendukung untuk mewujudkan sikap yang ingin dibentuk. Sebagai contoh siswa dibiasakan untuk bangun pukul 03.00 kemudian melakukan shalat tahajud rutin tidak bisa terbetuk melalui keinginan siswa sebagai individu saja, akan tetapi hal ini juga merupakan budaya dari kehidupan sosial yang ada di asrama. Kehidupan

Moh. Wahyu K, Rini S. Penanaman Nilai-Nilai Pendidikan Antikorupsi Melalui Habitus Keteladanan di SMP Muhammadiyah Boarding School Yogyakarta 
sosial akan menciptkan sebuah sistem yang mengikat perilaku siswa dalam membentuk habit. Hal inilah yang mendorong siswa untuk terbiasa melakukan semua kegiatan di asrama dengan tertib, karena jika mereka tidak tertib akan menjadi berbeda dari kehidupan sosial di asrama serta tidak menjadi bagian dari lingkungan tersebut.

Kehidupan sosial di asrama yang membentuk habit tertib, disiplin, mandiri, jujur serta tanggung jawab akan menjadi karakter dari siswa. Kaitannya dengan nilai-nilai pendidikan antikorupsi kehidupan sosial ini telah membantu membentuk nilai-nilai tersebutt dalam diri siswa. Sehingga dapat dikatakan untuk membentuk sebuah karakter baik harus didukung dengan lingkungan kehidupan sosial yang baik. Demikian juga untuk membentuk sikap atau karakter antikorupsi maka kehidupan sosial yang di biasakan pada siswa juga harus mencerminkan hal yang sama sebagai bentuk pembelajaran secara eksplisit. Inilah yang dalam terminologi Birdoue disebut sebagai habitus dibentuk oleh pengalaman dan pengajaran yang ekspilisit (Jenkins, 2010: 109).

\section{Pembiasaan Pendidikan Antikorupsi dalam Kegiatan Ekstrakulikuler}

Pembiasaan mengenai nilai-nilai pendidikan antikorupsi yang dilakukan SMP Muhammadiyah Boarding School Yogyakarta, selain pembiasaan melalui budaya sekolah dan kegiatan di asrama juga melalui kegiatan ekstrakulikuler, diharapkan dengan kegiatan ekstrakulikuler dapat memberikan pengalaman hidup langsung pada siswa tentang nilai-nilai antikorupsi. Melalui kegiatan ektrakulikuler siswa dilatih untuk megembangkan minat dan bakat siswa, memupuk rasa tanggung jawab, kedisiplinan, kemandirian, keberanian, toleransi dan value-value lainnya sebagai wujud nilai-nilai pendidikan antikorupsi. Proses pembiasaan melalui ekstrakulikuler harus mendapatkan pendampingan dari guru serta pengurus lainnya, agar value yang ditanamkan dapat tersampaikan dengan baik.

SMP Muhammadiyah Boarding School memiliki banyak ektrakulikuler dibagi menjadi dua kategori yaitu, ekstrakulikuler wajib dan pilihan, ekstrakulikuler untuk siswa SMP yang wajib ialah hizbul wathan atau kepanduan serta tapak suci, ekstrakulikuler pilihan seperti kaligrafi, potografi, PMR, tata boga dan banyak tergantung minat para siswa, hal ini disampaikan oleh Bapak Agus Yulianto serta Bapak M. Fauzan Yaksya.

Aula juga mengatakan bahwa ada dua ektrakulikuler wajib di SMP Muhammadiyah Boarding School yaitu HW dan Tapak Suci. Ektrakulikuler wajib seperti Hizbul Wathan (HW) dalam proses pelaksanaannya mengembangkan nilai-nilai untuk membentuk siswa menjadi pribadi yang tangguh seperti kejujuran, kemandirian, kerja keras, kesederhanaan, tanggung jawab, kepedulian serta rasa nasionalisme. Ektrakulikuler HW dilaksanakan setiap hari rabu pukul 16.0017.00 WIB, dalam setiap memulai kegiatan HW dimulai dan diakhiri dengan apel seperti kegiatan kepanduan pada umumnya. Tujuan HW adalah untuk memperkokoh takwa, membentuk akhlak dan watak yang berdasarkan iman kepada Allah SWT.

Bapak M. Fauzan Yaksya sebagai pembina ekstrakulikuler memberikan pemaparan bahwa ekstra Hizbul Wathan dapat digunakan sebagai penanaman nilainilai karakter yang didalamnya juga termasuk nilai-nilai pendidikan antikorupsi seperti kejujuran, kepemimpinan, kedisiplinan, kemandirian, kerja keras serta memupuk rasa kepedulian para siswa terhadap sesama. 
Nilai kejujuran dalam ekstrakulikuler Hizbul Wathan terlihat dari cara pengelolaan organisasi oleh para dewan kerabat. Dewan kerabat merupakan kepengurusan yang dibentuk untuk melatih kemandirian serta kepemimpinan siswa melalui seleksi. Siswa yang lolos seleksi menjadi dewan kerabat memiliki tugas dan tanggung jawab untuk mengelola kepengurusan Hizbul Wathan secara menyeluruh, dewan kerabat dibekali dengan kemampuan kepemimpinan, pengetahuan kepanduan atau kepramukaan, pengetahuan teknologi dan kemiliteran. Terkait dengan pembiasaan nilai-nilai pendidikan antikorupsi dewan kerabat disiapkan sebagai contoh pembiasaan dan teladan memupuk nilainilai kejujuran, kedisipinan, kemandirian, kepemimpinan, serta kedisiplinan. M.Fauzan Yaksa juga menyatakan bahwa, kedisiplinan tercermin dari kegiatan yang dilakukan sesuai dengan jadwal.

Nilai tanggung jawab sebagai bagian dari pendidikan antikorupsi tercermin dari adanya persiapan-persiapan yang dilakukan sebelum kegiatan dilaksanakan, mengikuti acara pembekalan merupakan wujud dari tanggung jawab menyiapkan kegiatan. Disamping itu kemandirian tercermin dari para dewan kerabat yang membuat, melaksanakan, serta mengevaluasi sendiri kegiatan HW, hal ini membantu kerja pembina untuk memantau kegiatan serta melatih dewan kerabat untuk dapat mandiri.

Kegiatan ekstrakulikuler dijadikan sebagai tempat untuk berlatih mengelola sebuah organisasi khususnya ekstrakulikuler HW dengan dewan kerabatnya. Penanaman nilai-nilai pendidikan antikorupsi seperti kejujuran dibiasakan dengan kegiatan real dari proses yang dilakukan oleh dewan kerabat dalam mengelola keuangan. Dewan kerabat merupakan pengurus dari HW yang berasal dari para siswa terpilih MBS, dijadikan sebagai pengurus serta pengelola organisasi. Kedisiplinan tercermin dari jadwal kegiatan yang tersusun dengan rapi serta dijalankan sesuai dengan aturan oleh para anggota HW.

Sementara itu tanggung jawab dibiasakan melalui kepercayaan yang diberikan oleh pembina dalam melaksanakan kegiatan yang telah direncanakan. Rasa tanggung jawab yang dimiliki oleh siswa merupakan ciri bahwa mereka merupakan manusia yang beradab (berbudaya). Siswa sebagai seorang manusia memiliki rasa tanggung jawab karena menyadari adanya akibat baik dan buruk dari perbuatannya. Pemupukan rasa tanggung jawab melalui kegiatan ekstrakulikuler diharapkan dapat membentuk karakter-karakter antikorupsi dalam diri siswa dengan menjadi pribadi yang bermoral.

Selanjutnya nilai-nilai kemandirian, kerja keras, kesederhanaan dan peduli sesama juga tercermin dari kegiatankegiatan yang dilakukan oleh para siswa. Kegiatan ekstrakulikuler dapat dikatakan sebagai wadah atau simulasi dari kehidupan di masyarakat. Pengalaman yang diperoleh oleh siswa melalui serangkaian kegiatan ekstrakulikuler akan membentuk habit yang menjadi karakter baik bagi siswa, hal ini sesuai dengan teori habitus Bourdie yang menyatakan bahwa habitus dibentuk oleh pengalaman dan pengajaran yang eksplisit (Jenkins, 2010:109). Sehingga pembiasaan memberikan pengaruh yang luar biasa pada perkembangan karakter siswa melalui pengalaman yang diperoleh secara mandiri.

\section{SIIMPULAN}

Strategi pengintegrasian pendidikan antikorupsi melalui pembiasaan dilakukan

Moh. Wahyu K, Rini S. Penanaman Nilai-Nilai Pendidikan Antikorupsi Melalui Habitus Keteladanan di SMP Muhammadiyah Boarding School Yogyakarta 
melalui budaya sekolah, asrama serta kegiatan ekstrakulikuler.

Pembiasaan nilai-nilai pendidikan antikorupsi tidaklah mudah untuk itu memerlukan kesungguhan serta dedikasi yang tinggi dari semua pihak untuk mewujudkan karakter antikorupsi. Tujuan dari pembiasaan nilai-nilai pendidikan antikorupsi adalah membentuk mental antikorupsi siswa dengan penanaman nilainilai kejujuran, kemandirian, kedisiplinan, keadilan, keberanian, kemandirian, kesederhanaan, kepedulian serta kreatifitas siswa. pendidikan antikorupsi akan melahirkan generasi penerus bangsa yang tangguh dengan mental antikorupsi untuk membangun peradaban bangsa.

\section{SARAN}

Bagi pihak sekolah untuk konsisten dan berkelanjutan dalam menghabituasikan nilai-nilai pendidikan antikorupsi seperti kejujuran, larangan mencontek, kedisiplinan, tanggung jawab, keberanian, kesederhanaan dan lain-lain melalui kegiatan intrakulikuler, ekstrakulikuler, serta budaya sekolah.

Kedepannya dilakukan penelitian serupa dengan mengambil sampel yang lebih besar tidak hanya pada sekolah dengan sistem boarding school namun juga sekolah biasa pada umumnya, sehingga mempermudah dalam generalisasi strategi pengintegrasian pendidikan antikorupsi.

\section{DAFTAR PUSTAKA}

Transparancy International. (2015). Corruption perseptions index 2015. Diambil pada 04 Januari 2017, dari http://www.transparency.org/ cpi2015?gclid=Cj0KEQiAtK3DBRCBxtYxduq5p4BEiQAbFiaPdCJLTz $\mathrm{n}$ i h d z a e u $\mathrm{U} 6 \mathrm{z} \mathrm{Q}$ i e o $02 \mathrm{H} \mathrm{m}$ 0BQ5KIDnGyefu60aAg4g8P8HAQ.
Nuriani Laura, Haris, M., \& Samsi, H. (2014). Implementasi pendidikan antikorupsi melalui warung kejujuran di smp keluar kudus. Jurnal Teknologi Pendidikan dan Pembelajaran Vol. 2, No. 1, 93-102.

Dharma Kesuma, Cecep Darmawan, \& Johar Permana. (2009). Korupsi dan pendidikan antikorupsi. Bandung: Pustaka Aulia Press.

Agus Wibowo. (2013). Pendidikan antikorupsi di sekolah: strategi internalisasi pendidikan antikorupsi di sekolah. Yogyakarta: Pustaka Pelajar.

Rosida Tiurma M. (2012). Pendidikan antikorupsi sebagai satuan pembelajaran berkarakter dan humanistik. Jurnal Sosioteknologi, Vol. 27, No. 11, 232-244.

Lukman Hakim. (2012). Model integrasi pendidikan antikorupsi dalam kurikulum pendidikan islam. Jurnal Pendidikan Agama Islam-ta'lim Vol. 10, No. 2.

Harmanto. (2008). Mencari model pendidikan antikorupsi bagi siswa SMP dan MTs. Makalah disampaikan dalam simposium nasional pendidikan, di Universitas Negeri Surabaya.

Edi Sudrajat. (2011). "Pengaruh pembelajaran pendidikan kewarganegaraan dan habituasi terhadap kesadaran lingkungan peserta didik SMP". Tesis tidak diterbitkan, Universitas Pendidikan Indonesia, Yogyakarta.

Jenkins, R. (2010). Membaca pikiran pierre bourdie. (Terjemahan Nurhadi). London: Roultedge. (Buku asli diterbitkan tahun 1992). 